\title{
Resistance to Starvation of Triatoma rubrofasciata (De Geer, 1773) under Laboratory Conditions (Hemiptera: Reduviidae: Triatominae)
}

\author{
Mirko G Rojas Cortéz, Teresa Cristina M Gonçalves*/+
}

\begin{abstract}
Laboratório Nacional e Internacional de Referência em Taxonomia de Triatomíneos *Núcleo de Morfologia, Anatomia Interna e Ultraestrutura de Artrópodos Vetores, Laboratório de Transmissores de Leishmaniose e

Oncocercose, Departamento de Entomologia, Instituto Oswaldo Cruz, Av. Brasil 4365, 21045-900

Rio de Janeiro, RJ, Brasil
\end{abstract}

The present work aims at learning the period of resistance to starvation (molting/death) of Triatoma rubrofasciata in different stages of development and the respective loss of weight until death. Eggs of specimens from the greater area of the city of São Luis in the State of Maranhão, Brazil, yielded approximately 300 nymphs. These nymphs were placed in labelled Borrel glasses, in which they were weekly fed on rats (Rattus norvegicus), until reaching the stage to be observed. The experiments were conducted in a climatic chamber regulated at $29 \pm 1^{\circ} \mathrm{C}, 70 \%$ relative humidity and $12 \mathrm{hr}$ photoperiod. The resistance to starvation increased according to the stage of development, except for adult bugs, whose results were similar to the $3 \mathrm{rd}$ stage nymphs. In all these development stages there was an abrupt loss of weight in the first week, followed by a gradual loss until death. Comparing this work with those of other authors, it was observed that $\mathrm{T}$. rubrofasciata is among the less resistant triatomine species.

Key words: Triatoma rubrofasciata - resistance to starvation

Triatoma rubrofasciata (De Geer, 1773), cosmopolitan species distributed geographically between the tropics of Cancer and Capricorn, is most commonly found in Asia, Oceania, Africa and Central America. In South America, its distribution is restricted to Venezuela, French Guyana, Brazil and Argentina (Dias \& Seabra 1943, Lent \& Wygodzinsky 1979). In Brazil, its presence was detected in all the major harbors [Bahia, Rio de Janeiro, Santos (SP) and Maranhão], but only in Pernambuco has the species established itself (Lucena 1959). Fuentes et al. (1971) disclosed the presence of this species adapted in domiciles in São Cristóvão district (RJ), a fact confirmed by the presence of eggs and young forms in the residences examined. In the same way, Brasil and Silva (1983) obtained the same results in the Island of São Luis (MA).

T. rubrofasciata is totally domiciliated, with urban characteristics intimately related to socioeconomic factors of many capitals and seashore

\footnotetext{
This work was supported by BIRD/FNS/FIOCRUZ contract number 027/93.

${ }^{+}$Corresponding author. Fax: +55-21-290.9339. E-mail: tcmonte@gene.dbbm.fiocruz.br

Received 12 January 1998

Accepted 15 May 1998
}

places (Zeledón 1974). It is frequently associated to rodents, and naturally infected by Trypanosoma conorrhini, which is not pathogenic to man (Deane 1947).

The natural infection of $T$. rubrofasciata by Trypanosoma cruzi was detected by Dias and Neves (1943), Lucena and Marques (1955), Costa (1955) apud Fuentes et al. (1971), Sherlock and Serafim (1974), Brasil and Silva (1983), and Leal et al. (1965) apud Brasil (1986). However, in spite of being a domiciliated species, it has no epidemiological importance except in the seashore zone - Pernambuco forest, where it seems adapted as a natural vector of T. cruzi (Fuentes et al. 1971).

Recently, the Fundação Nacional de Saúde (FNS) from Brazil has blamed T. rubrofasciata, a species that is moving towards the countryside along with the rodents. Until then, this triatomine was restricted to harbor areas from the State of Maranhão (personal communication). This behavior has been worrying the authorities, since it will enable the contact with $T$. cruzi reservoirs, increasing the chances of T. rubrofasciata's infection and, consequent transmission.

The lack of information on this species may be justified by the fact that it did not represent a risk to the population until then. However, facts as the one observed by the FNS put in evidence the necessity of studies using such approach. 
One of the aspects of the biological triatomine behaviour that deserves to be observed is the resistance to starvation, enabling them to stand long periods of food deprivation. This facilitates the passive transportation, mostly in the young forms, colonizing new habitats, the appearance of new spots of Chagas disease (Pellegrino 1952) and the maintenance of infestations in domicile and other temporarily abandoned dwellings (Feliciangeli et al. 1980).

The objetive of this study is to learn about the capacity of resistance to starvation of $T$. rubrofasciata in the period between ecdises and death in its different stages of development, contributing to the comprehension of its behaviour and to the planning of control actions.

\section{MATERIALS AND METHODS}

The study was initiated with eggs obtained from T. rubrofasciata species, natural from the urban area of São Luis, State of Maranhão, Brazil.

Right after eclosion the nymphs were placed in Borrel glasses, which were identified and closed with nylon nets containing in its interior two pieces of filter-paper: one at the bottom and another folded several times to enlarge the surface of contact and eliminate the excess of humidity. This process was repeated as the ecdysis of different stages had occurred, until the nymphs reached the stage established to start the starvation. Fifty specimens of each stage were observed.

The feeding was taken from rats (Rattus norvegicus from the breed Wistar) in two ways: for the nymphs of 1st, 2nd and 3rd stages, the ani- mal was kept immobile in a nylon net bag with a round hole on the dorsal region, which was shaved for placing the Borrel glasses. For the nymphs at 4th and 5th stages, the animal was also kept immobile in a nylon net bag and left inside a glass container closed with a nylon net. The container was darkened with a black carton around it in order not to disturb feeding insects. The blood meal was offered weekly during the required time for the bugs to reach repletion.

The initial weight corresponded to the day the ecdysis occurred. For the 1st, 2nd and 3rd stages three weekly weighings were made to observe the gradual loss of weight until death. For nymphs on 4th and 5th stages and adults the weighings were made twice a week, since it was not possible to observe differences in their weight by weighing them three times a week.

During experiments the insects were kept in a climatic chamber at $29 \pm 1{ }^{\circ} \mathrm{C}, 70 \pm 10 \% \mathrm{RH}$ and 12 hr photoperiod.

\section{RESULTS}

Table I shows that the resistance increased in accordance with the stage of development, except for the adult bugs that presented resistance similar to the 3rd stage nymphs, but less than those in the 4th stage. The shortest resistance was observed in the 2nd stage and the longest in the 5th stage.

The loss of weight presented on Table II was gradual according to the stage of development, being the smallest registered for the 1st stage nymphs and the largest for the adults.

TABLE I

Resistance to starvation (in days) of Triatoma rubrofasciata

\begin{tabular}{llccrr}
\hline $\begin{array}{l}\text { Evolutive } \\
\text { stage }\end{array}$ & $\mathrm{N}$ & \multicolumn{3}{c}{ Amplitude } & $\begin{array}{r}\text { Standard } \\
\text { deviation }\end{array}$ \\
\cline { 3 - 5 } & & Minimum & Maximum & Mean & 1.95 \\
1st instar & 50 & 17 & 24 & 21.64 & 10.08 \\
2nd instar & 50 & 7 & 53 & 24.12 & 10.64 \\
3rd instar & 50 & 28 & 63 & 46.80 & 17.77 \\
4th instar & 50 & 39 & 112 & 77.90 & 24.09 \\
5th instar & 50 & 35 & 172 & 101.58 & 9.19 \\
Adults & 50 & 25 & 67 & 51.44 & \\
\hline
\end{tabular}

TABLE II

Loss of weight (mg) during the starvation of Triatoma rubrofasciata

\begin{tabular}{|c|c|c|c|c|c|}
\hline \multirow{2}{*}{$\begin{array}{l}\text { Evolutive } \\
\text { stage }\end{array}$} & \multirow[t]{2}{*}{$\mathrm{N}$} & \multicolumn{3}{|c|}{ Amplitude } & \multirow{2}{*}{$\begin{array}{l}\text { Standard } \\
\text { deviation }\end{array}$} \\
\hline & & Minimum & Maximum & Mean & \\
\hline 1st instar & 50 & 0.4 & 0.74 & 0.58 & 0.11 \\
\hline 2nd instar & 50 & 1.0 & 3.89 & 2.03 & 0.65 \\
\hline 3rd instar & 50 & 4.4 & 7.80 & 5.38 & 1.01 \\
\hline 4th instar & 50 & 10.0 & 30.14 & 15.97 & 4.40 \\
\hline 5th instar & 50 & 31.0 & 73.12 & 44.16 & 9.20 \\
\hline Adults & 50 & 63.0 & 173.42 & 103.63 & 31.69 \\
\hline
\end{tabular}


The association between mortality occurrence and loss of weight observed for the different stages of development are presented in the Figure. The largest percentage of mortality and the respective periods of days registered for the 1st, $2 \mathrm{nd}, 3 \mathrm{rd}, 4 \mathrm{th}$ and 5th stages and adults were $46 \%$ (20th-22nd day); $60 \%$ (14th-25th day); $28 \%$ (35th-42nd day); $50 \%$ (63rd-84th day); 54\% (95th-116th day) and $78 \%$ (42nd-63rd day), respectively.

In all developmental stages there was an abrupt loss of weight in the first week followed by a gradual loss until death. However, oscillations in determined days of the weight loss period were observed in nymphs of the 2nd to the 5th stage and adult bugs, with exception of the 1st stage nymphs.

\section{DISCUSSION}

Studies made with other species of triatomines showed that the difference in conditions (temperature, humidity and food source) makes it difficult to compare results (Jurberg \& Costa 1989).

The resistance to starvation from ecdysis until death obtained by various authors (Table III), compared with the present work, demonstrated that $T$. rubrofasciata was more resistant than Rhodnius neglectus (Lent 1954) in all stages than Cavernicola lenti (Barrett \& Arias, 1985) in 1st, 3rd, 4th, 5th stages and adult bugs and than Triatoma brasiliensis (Neiva, 1911) in 3rd, 4th and 5th stages. In the latter the results among the adult bugs were similar for the males, which were more resistant than the fe-
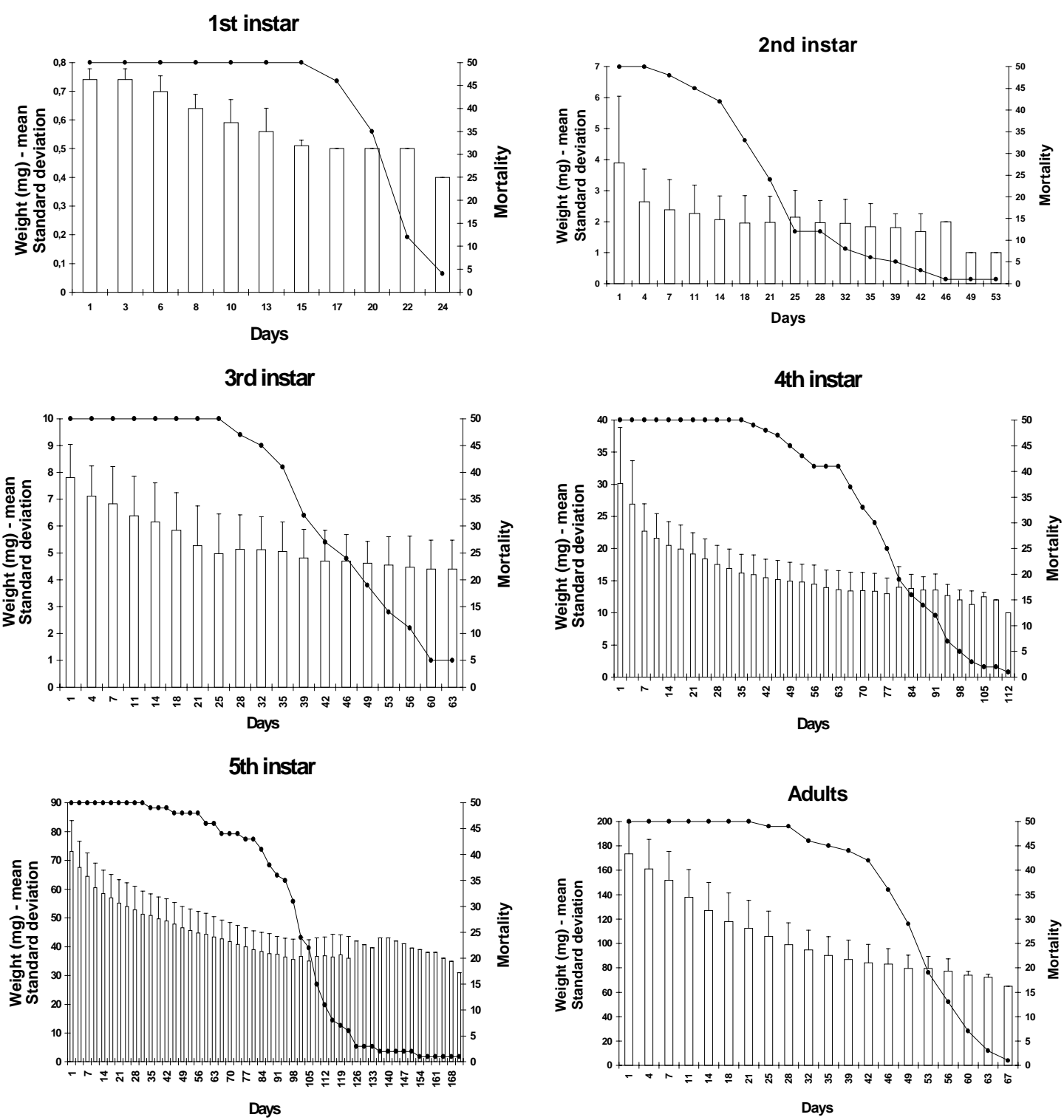

Resistance to starvation and loss of weight of Triatoma rubrofasciata in differents stages of development until death. 
TABLE III

Comparative results of starvation (in days) of different species

\begin{tabular}{|c|c|c|c|c|c|c|c|c|c|c|c|}
\hline \multirow{2}{*}{ Species } & \multicolumn{5}{|c|}{ Nymphs } & \multicolumn{2}{|c|}{ Adults } & \multirow{2}{*}{$\begin{array}{c}\text { Temp. } \\
{ }^{\circ} \mathrm{C}\end{array}$} & \multirow{2}{*}{$\begin{array}{c}\text { Umid. } \\
\%\end{array}$} & \multirow{2}{*}{$\begin{array}{l}\text { Blood } \\
\text { source }\end{array}$} & \multirow{2}{*}{ Authors } \\
\hline & $1 \mathrm{st}$ & 2nd & $3 \mathrm{rd}$ & 4th & 5 th & Males & Females & & & & \\
\hline C. lenti & 15.50 & 33.50 & 40.26 & 71.55 & 75.64 & 41.76 & 44.82 & 28 & 90 & mice & Costa \& Jurberg 1989 \\
\hline D. maximus & 58.00 & 85.00 & 115.00 & 103.00 & 124.00 & 80.00 & 78.00 & 28 & 65 & mice & Costa et al. 1987 \\
\hline D. maximus & 67.00 & 74.00 & 89.00 & 82.00 & 83.00 & 59.00 & 52.00 & 28 & 65 & pigeon & Costa et al. 1987 \\
\hline R. neglectus & 13.00 & 22.00 & 30.50 & 41.00 & 66.50 & 51.50 & 57.50 & 26 & 75 & $*$ & Costa et al. 1967 \\
\hline$R$. prolixus & 44.64 & 91.00 & 164.90 & 161.60 & 114.75 & $*$ & $*$ & ambient & $*$ & bird & Feliciangeli 1980 \\
\hline T. brasiliensis & 33.30 & 44.23 & 40.28 & 48.00 & 58.46 & 52.33 & 42.63 & 30 & $70-80$ & mice & Costa \& Perondini 1973 \\
\hline T. brasiliensis brasiliensis & 35.82 & 40.04 & 50.50 & 67.97 & * & $*$ & $*$ & 29.1 & 71.81 & mice & Costa \& Marchon-Silva 1996 \\
\hline T. brasiliensis macromelasoma & 38.39 & 42.44 & 60.84 & 76.77 & $*$ & $*$ & $*$ & 29.1 & 71.81 & mice & Costa \& Marchon-Silva 1996 \\
\hline T. brasiliensis melanica & 38.79 & 39.86 & 62.37 & 80.57 & $*$ & $*$ & $*$ & 29.1 & 71.81 & mice & Costa \& Marchon-Silva 1996 \\
\hline T. brasiliensis $(?)$ & 43.32 & 50.13 & 56.69 & 68.00 & $*$ & $*$ & $*$ & 29.1 & 71.81 & mice & Costa \& Marchon-Silva 1996 \\
\hline T. dimidiata & 29.90 & 32.90 & 80.90 & 79.80 & 118.80 & 73.30 & 73.00 & ambient & $*$ & chicken & Zeledón et al. 1970 \\
\hline T. infestans & 60.20 & 49.40 & $*$ & 86.30 & 76.40 & $*$ & $*$ & ambient & $*$ & chicken & Perlowagora-Szwumlewicz 1969 \\
\hline T. lecticularia & 45.84 & 61.00 & 88.74 & 123.47 & 162.30 & 88.94 & 83.66 & $*$ & $*$ & pigeon & Jurberg \& Costa 1989 \\
\hline T. rubrofasciata & 21.64 & 24.12 & 46.80 & 77.90 & 101.58 & \multicolumn{2}{|c|}{51.44} & 29 & 70 & mice & Cortéz \& Gonçalves (this paper) \\
\hline T. sordida & 46.70 & 72.20 & 118.00 & 176.70 & 217.80 & 54.90 & 63.90 & 25 & $60-70$ & mice & Juarez \& Silva 1982 \\
\hline T. sordida & 22.30 & 33.60 & 54.80 & 76.70 & 108.00 & 38.30 & 40.70 & 30 & $60-70$ & mice & Juarez \& Silva 1982 \\
\hline T. vitticeps & 37.00 & 91.00 & 136.00 & 177.00 & 180.00 & 63.00 & 58.00 & ambient & $*$ & mice & Gonçalves et al. 1989 \\
\hline T. vitticeps & 67.00 & 81.60 & 122.00 & 108.10 & 112.90 & 73.60 & 61.50 & 25 & 70 & chicken & Silva 1985 \\
\hline T. vitticeps & 40.80 & 54.90 & 66.30 & 76.40 & 80.20 & 45.40 & 45.10 & 30 & 70 & chicken & Silva 1985 \\
\hline
\end{tabular}

* : without information; C: Cavernicola; D: Dipetalogaster; R: Rhodnius; T: Triatoma 
males. The same occurred with adults of Triatoma sordida (Stal, 1859) and Triatoma vitticeps (Stal, 1859) at the temperature of $30^{\circ} \mathrm{C}$.

Regarding T. rubrofasciata it was observed that the weight reduction in all stages were generally gradual, but that in 2nd, 4th and 5th stages, and in a lower degree in 1st, 3rd and in adult bugs, an abrupt loss of weight occured in the 1st week soon after the ecdysis, phenomenon that was also observed in T. brasiliensis by Costa and Perondini (1973).

In certain days of the experiment, it was observed that the weight loss for the nymphs from 2nd to 5th stage and adult bugs increased in the average weight, probably related to the individual weight of each specimen that reached these intervals, altering in such way the medium weight of the sample. This observation may be justified by the comments of Jurberg and Costa (1989) who observed a great variation of weight in a same stage. These facts can be confirmed by the results obtained in the present work for the 1st stage nymphs, not being observed any increasing or weight variation, once they initiated starvation with egg's storage only, which determined their survival time.

The effectiveness of control campagnes against these vectors could be affected by their resistance to starvation, since it enables the bugs to remain in their shelters, free from the insecticide and sometimes from its residual effect, increasing the chances for a possible recolonization by remaining individuals (Dias 1965, Perlowagora-Szumlewicz 1969).

The cannibalism, behavior observed among the triatomines (Zeledón 1983), occurred in the present work when nymphs of 2nd and 3rd stage fed on 4th and 5th stage nymphs and on adult insects. In the latter, cannibalism occurred in the end of the molting, when the cuticle was not totally hardened and the insect presented low mobility. In their natural habitat, and under adverse conditions, this behavior should contribute to the survival of younger nymphs, making possible the maintenance of the natural infection by T. cruzi (Schaub 1988).

The fact that $T$. rubrofasciata is among the species that present lower resistance to starvation bring good perspectives to the success of controlling works.

\section{ACKNOWLEDGMENTS}

To the Fundação Nacional da Saúde and to Prof. Elias Seixas Lorosa for the capture of specimens of $T$. rubrofasciata in the State of Maranhão.

\section{REFERENCES}

Brasil RP 1986. Observations on the feeding habitats of Triatoma rubrofasciata (Hemiptera: Reduviidae). Trans $R$ Soc Trop Med Hyg 80: 349.
Brasil RP, Silva AR da 1983. Triatomine vectors of Trypanosoma cruzi like trypanosomes in urban areas of São Luiz, Maranhão, Brasil. Trans R Soc Trop Med Hyg 77: 568.

Costa JM, Jurberg J 1989. Estudos sobre a resistência ao jejum e aspectos nutricionais de Cavernicola lenti Barrett \& Arias, 1985 (Hemiptera, Reduviidae, Triatominae). Mem Inst Oswaldo Cruz 84:129-137.

Costa JM, Marchon-Silva V 1996. Studies on the starvation period of different melanic forms of Triatoma brasiliensis Neiva, 1911 (Hemiptera, Reduviidae, Triatominae). Mem Inst Oswaldo Cruz 91 (Suppl): 144.

Costa MJ, Perondini ALP 1973. Resistência do Triatoma brasiliensis ao jejum. Rev Saúde Públ São Paulo 7: 207-217.

Costa HM de A, Costa JO, Freitas MG 1967. Alguns aspectos da biologia do Rhodnius neglectus Lent, 1954 (Hemiptera, Triatominae) em condições de laboratório III - Resistência ao jejum. Arq Esc Vet XIX: 147-155.

Costa JM, Jurberg J, Almeida JR 1987. Estudos bionômicos de Dipetalogaster maximus (Uhler, 1894) (Hemiptera, Triatominae). II Influência da dieta sobre o ciclo biológico e resistência ao jejum. Mem Inst Oswaldo Cruz 82: 111-118.

Deane MP 1947. Ocorrência do Trypanosoma conorrhini em "barbeiros" e em rato na cidade de Belém, Pará, e seu cultivo em meio de NNN. Rev Serv Espec Saúde Pública 1: 433-448.

Dias JCP 1965. Observações sobre o comportamento de triatomíneos brasileiros frente ao jejum, em laboratório. Rev Bras Malariol D Trop 17: 55-63.

Dias E, Neves O 1943. Determinação da infecção natural por Schizotrypanum em Triatoma rubrofasciata no Estado de Pernambuco. Mem Inst Oswaldo Cruz 39: 331-334.

Dias E, Seabra CAC 1943. Sôbre o Trypanosoma conorrhini, hemoparasito do rato transmitido pelo Triatoma rubrofasciata. Presença do vector infectado na cidade do Rio de Janeiro. Mem Inst Oswaldo Cruz 39: 301-329.

Feliciangeli D, Rabinovich J, Fernández E 1980. Resistencia al ayuno en triatominos (Hemiptera, Reduviidae) Venezolanos. I. Rhodnius prolixus Stal. Rev Inst Med Trop São Paulo 22: 53-61.

Fuentes FB, Coura JR, Ferreira LF 1971. Observações sôbre o Triatoma rubrofasciata (De Geer, 1773) no estado da Guanabara. Rev Soc Bras Med Trop 5: 4753.

Gonçalves TCM, Victório VMN, Jurberg J, Cunha V 1989. Biologia do Triatoma vitticeps (Stal, 1859) em condições de laboratório (Hemiptera, Reduviidae, Triatominae) II. Resistência ao jejum. Mem Inst Oswaldo Cruz 84: 131-134.

Juarez E, Silva E P de C 1982. Comportamento do Triatoma sordida em condições de laboratório. Rev Saúde Públ 16:1-36.

Jurberg J, Costa MJ 1989. Estudos sobre a resistência ao jejum e aspectos nutricionais de Triatoma lecticularia (Stal, 1859) (Hemiptera, Reduviidae, Triatominae). Mem Inst Oswaldo Cruz 84: 393-399. 
Lent H, Wygodzinsky P 1979. Revision of the Triatominae (Hemiptera, Reduviidae), and their significance as vector of Chagas' disease. Bull Amer Mus Nat History 163: 123-520.

Lucena DT 1959. Ecologia dos Triatomíneos do Brasil. Rev Bras Malariol D Trop 11: 577-635.

Lucena DI, Marques RJ 1955. Subsídios para o estudo ecológico do Triatoma rubrofasciata no Brasil. An Fac Med Univ Recife 15: 19-31.

Pellegrino J 1952. Observações sôbre a resistência do Triatoma infestans ao jejum. Rev Brasil Biol 12: 317 320.

Perlowagora-Szumlewicz A 1969. Estudos sobre a biologia do Triatoma infestans, o principal vetor da doença de Chagas no Brasil (Importância de algumas de suas características biológicas no planejamento de esquemas de combate a esse vetor). Rev Bras Malariol D Trop 21: 117-159.

Schaub GA 1988. Direct transmission of Trypanosoma cruzi between vectors of Chagas disease. Acta Tropica 45: 11-19.

Sherlock IA, Serafim EM 1974. Fauna Triatominae do Estado da Bahia, Brasil. VI. Prevalência geográfica da infecção dos triatomíneos por T. cruzi. Rev Soc Bras Med Trop 8: 129-142.

Silva IG 1985. Influência da Temperatura na Biologia de 18 Espécies de Triatomíneos (Hemiptera: Reduviidae) e no Xenodiagnóstico, Tese de Mestrado, Univ. Federal do Paraná, Curitiba, 169 pp.

Zeledón R 1974. Los vectores de la enfermedad de Chagas en America. An Simp Intern Doença de Chagas, Buenos Aires: 327-345.

Zeledón R 1983. Vectores de la enfermedad de Chagas y sus características ecofisiologicas. Interciencia 8 : 384-395.

Zeledón R, Guardia VM, Zuñiga A, Swartzwelder JC 1970. Biology and ethology of Triatoma dimidiata (Latreille, 1811). J Med Ent 7: 313-319. 